\title{
THE URUGUAYAN FUR-SEAL ISLANDS
}

\section{By Hugh M. SMith}

(Figs. 294-300 incl.)

In the United States there is a widespread popular notion that fur seals are restricted to the North Pacific Ocean, and the assertion that there are fur-seal herds in the southern hemisphere occasions surprise to many people. In the fur markets of the world, however, seal skins with soft, dense hair have for more than a century been received from antarctic or far southern latitudes; and the fur trade has long been advised that seals with fur scarcely less beautiful than that possessed by the seals of Alaska exist in circumpolar waters of the southern hemisphere and range northward to the mainland of Africa and South America and to various islands of the South Atlantic, South Pacific, and South Indian oceans. A colony of southern fur seals occupied the Galapagos Islands ${ }^{1}$ off the coast of Peru; and a still more detached colony resorted to Guadeloupe Island ${ }^{2}$ off the coast of Lower California. These colonies were so long separated from the parent stock that they developed peculiar characters which entitle them to recognition as distinct species. Owing to lack of protection and to repeated raids by irresponsible people, the Galapagos and Guadeloupe seals are in danger of total extinction. ${ }^{3}$

Of the once mighty bands of fur seals that frequented the lands and waters of the far south, the principal remnants are now found on the coasts of Argentina and Uruguay. The largest existing herd and the only established sealing industry are off the northeastern shores of Uruguay. Very little has been written about the Uruguayan fur seals and fur-seal islands. Having had an opportunity to visit these islands and observe the seals, and being probably the only North American who has been to all the islands, I may be able to present some information of interest. The staunch little cablelaying steamer Salvor was made available by the Uruguayan government, and the visit was made in December, 1922.

\section{The Antarctic Fur Seals}

The southern fur seals have not received the comprehensive and long-continued study that has been given to the northern fur seals

${ }^{1}$ Arctocephalus philippi. ${ }^{2}$ Arctocephalus townsendi.

${ }^{3}$ The Guadeloupe seal was first described by Dr. C. Hart Merriam in 1897 and named by him for Dr. Charles H. Townsend, formerly naturalist on the Fish Commission steamer Albatross and now director of the New York Aquarium. 


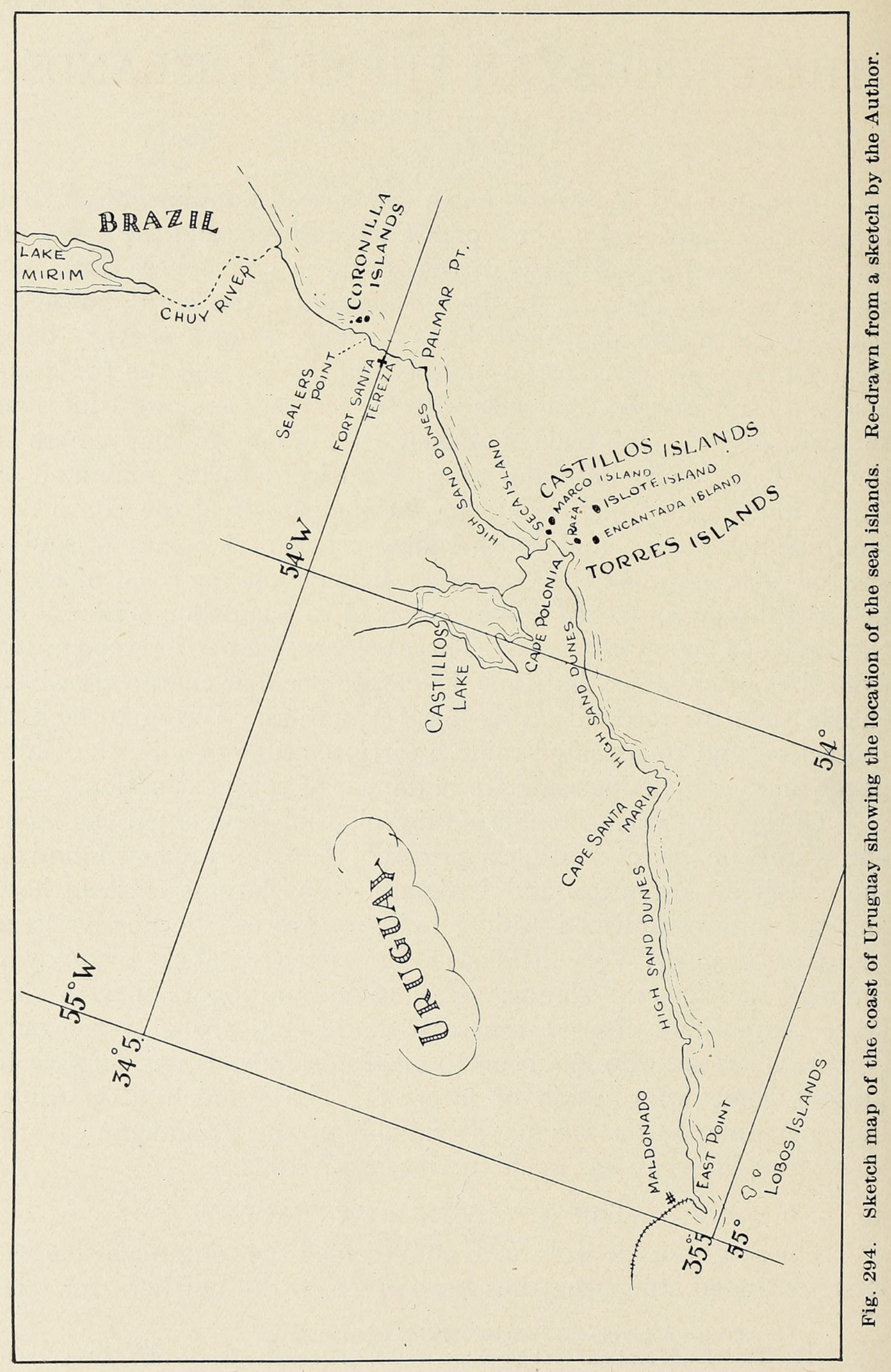


by zoologists. A person in quest of detailed facts regarding any important phase in the life of these creatures will look in vain in works of travel and reference. It is lamentable that the countries claiming ownership of the southern fur seals have not sought to acquire even the fundamental biological data as a prerequisite to the proper administration and utilization of the seal herds - their chief concern seems to have been to kill as many seals as could be killed, without regard to age, sex, or breeding requirements. It is true that much of the slaughter in earlier years was on remote islands easily raided by the sealers of foreign nations; but even under modern conditions, with the gruesome history of unrestricted sealing so well known and so often cited, and with the seals readily susceptible of protection, the countries most concerned have seemed indifferent to the present or future welfare of one of their most valuable resources.

The extensive north and south range of the antarctic fur seals and the wide separation of the different bands that used habitually to resort for breeding purposes to the shores of Africa and South America and to various remote islands led early zoologists to assign distinct names to the members of the different herds, and at least twenty-five nominal species were recognized. Even at the present time the early nomenclatural tangle has not been straightened out, owing to the deficiency of anatomical material at the disposal of zoologists. There is general agreement, however, that the fur seal found on islands off the east coast of South America should bear the specific name of australis first applied by Zimmerman in 1782 to the fur seal of the Falkland Islands. While the southern forms are true fur seals, they differ in cranial and other characters from the North Pacific fur seals (Callorhinus), and are given a distinct generic name Arctocephalus.

The southern fur seals have a rich, soft, luxuriant fur that for beauty is scarcely if at all inferior to that of the North Pacific fur seals. Even those branches of the tribe that frequent subtropical or tropical waters, where a thick coat is not needed for warmth, have a fur that is remarkable for its softness and denseness.

\section{Ruthless Slaughter of EARly Days}

The recognized commercial value of the pelts of the southern fur seals early attracted hunters from North America and Europe, and in the wholesale destruction that ensued the seals underwent 
almost total extinction in certain places. Thus, in 1798, the ship "Betsy" of New York took a full cargo of skins from the island of Masafuera, on the coast of Chile, and Captain Fanning reported that when he left the island there were 500,000 to 700,000 seals there. In the next few years a million seals were killed on that island. Captain Scammon reported that in 1801, 30 vessels, many of large size and nearly all under the United States flag, resorted to the island and killed without restraint. In 1815, when Captain Fanning again visited the island, he found only a few seals remaining.

At the island of South Georgia, discovered by Captain Cook in 1775 and found to possess extensive herds of fur seals which he very aptly called "sea-bears," the sealing business began early and reached its height in 1800, and not less than 112,000 skins were taken in one season, 57,000 of these by a single American vessel, the "Aspasia." This slaughter continued for 20 years and left only a small remnant. Dr. Robert C. Murphy (National Geographical Magazine, April, 1922) notes that in 1907 between 300 and 400 fur seals were slain illegally and since that time scarcely an animal has been reported from South Georgia. It is recorded by Captain Weddell that at the South Shetland Islands over 300,000 fur seals were killed in 1820 and 1821, and that at the end of 1821 the species was almost exterminated; not less than 100,000 newborn seals were starved to death because of the killing of their mothers, and the destruction was so ruthless that whenever a seal landed it was immediately dispatched.

Similar slaughter occurred at Antipodes Island, off New South Wales, where not less than 400,000 seals were killed in 1814 and 1815 . A single ship carried in bulk to London 100,000 skins which on arrival were found to be spoiled and were sold as manure.

By 1830 the fur seals of the southern seas had been so reduced in numbers that sealing vessels generally had a losing business. The known places that were the last resort of the seals had been abandoned by them; but owing to the considerable numbers of seals still observed at sea it was the belief of sealers that there were undiscovered grounds to which the seals were going for breeding purposes.

\section{EARLy SEALING IN URUguay}

Commercial sealing on the Uruguayan coast was carried on prior to 1820 ; and it is a matter of record that in 1823 the government, ap- 


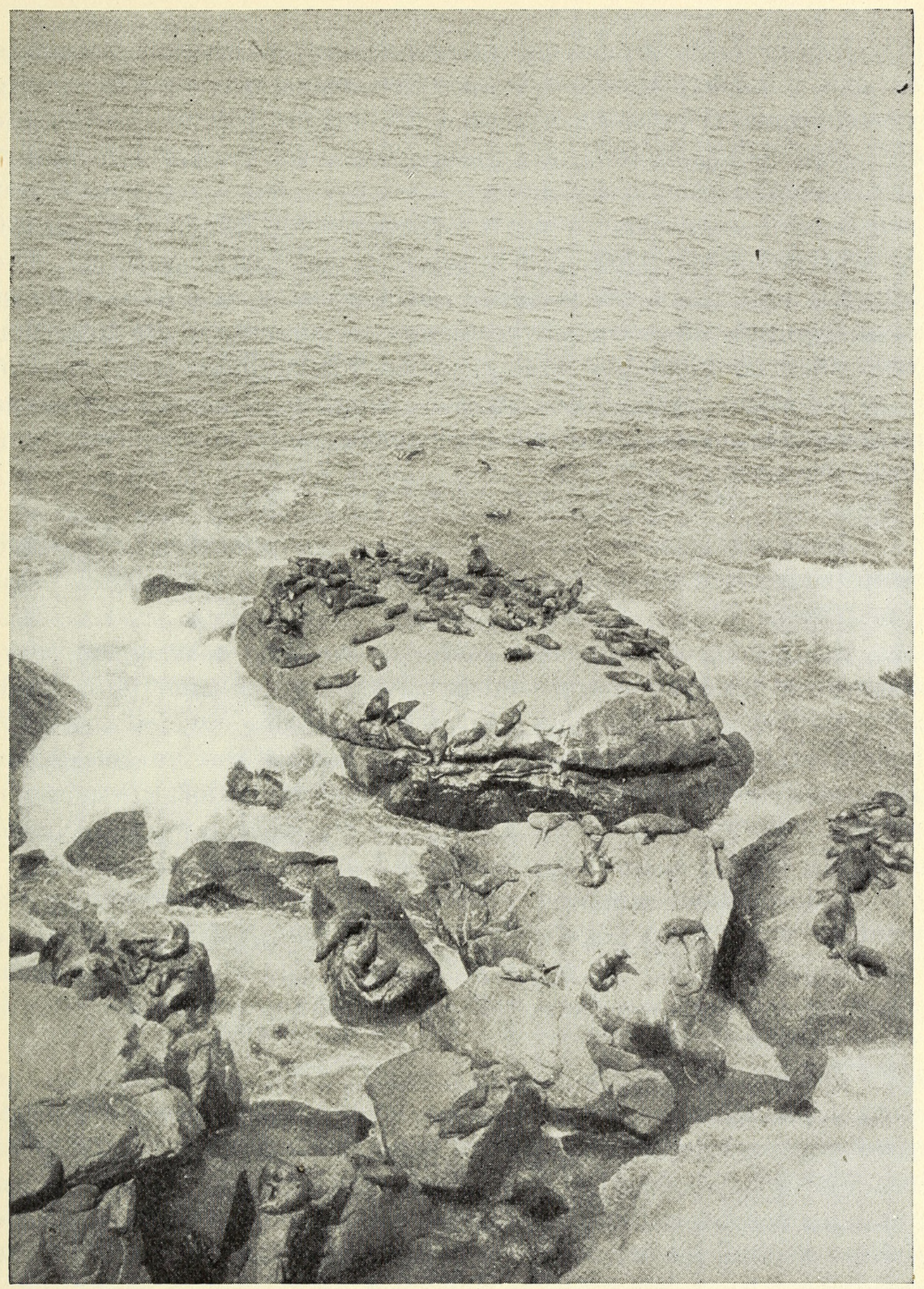

Fig. 295. Lobos Islands: Fur seals on a rocky ledge. 
parently desirous of deriving some revenue from fur seals, leased to an individual for the sum of $\$ 80,000$ the sealing privileges for a term of ten years. The leasing system continued until 1910. During the 35 years ending in 1907, the lessees placed on the London market 524,120 salted skins, an average of 15,000 annually. The largest numbers of seals taken in single seasons were 21,150 in $1888,20,150$ in $1890,20,763$ in $1894,23,639$ in 1896 , and 21,253 in 1902 . The smallest take was 5,633 in 1905 . It is reported that when the last lease expired, after the government had announced its intention henceforth to do its own sealing, the islands had been swept clear of every available seal. The only seals left were those on inaccessible islands and rookeries, or on the high seas beyond thelocal jurisdiction.

\section{Sea-lions Associated with Fur Seals}

Everywhere on the Uruguayan coast the fur seal has associated with it a related seal which, for lack of a better name, is called sealion (Otaria jubata). It belongs to the same family as the fur seals, the two having external ears and various other anatomical characteristics in common and the same bear-like movements on land. The sea-lion, however, has no fur, its body being covered with stiff hairs like those constituting the "guard" hairs of the fur seals. The old males develop a very conspicuous mane, and a local Uruguayan name for the creature is peluca (i. e., one who wears a wig). A book name is "Patagonian maned sea-lion."

This sea-lion, ranging on the entire coast of Uruguay and Argentina, extends up the west coast of South America as far as the Galapagos Islands. It was not listed by Dr. Murphy (National Geographic Magazine, April, 1922) among the seals inhabiting South Georgia Island.

The sea-lions appear to live amicably with the fur seals on the Uruguayan islands. Some stretches of the rocky shores are practically monopolized by them, while in other places small groups of sea-lions may be observed intermingled with fur seals. The largest sea-lions are larger than the largest fur seals, but it is said that the full-grown bull fur seals are able to maintain themselves against the sea-lions.

The most numerous group of sea-lions is to be found on the Lobos Islands. The principal rookery is quite near the village. I approached quite close to a part of this rookery, took photographs, 
and inadvertently stampeded about fifty old males that were sleeping at the water's edge, regularly lined up on a shelly beach. They took to the water with a tremendous splash, plunged through the surf, and then faced about and contemplated the stranger who had disturbed their slumber. Some of these were of huge proportions, weighing at least 1,000 pounds.

A singular feature of many of the old male sea-lions is the presence of large granite stones in their stomachs. The stones, of which 3 are often found in one animal, are sometimes 4 to 5 inches long and 2 to 3 inches thick, with well rounded ends and smooth sides. The sealers think the stones are deliberately taken in for ballast! A more plausible explanation, however, is that the stones are swallowed with the octopuses on which the sea-lions are known to feed and which attach themselves tightly to stones when in danger of capture.

Sea-lions are killed along with fur seals on the Uruguayan coast. Their skins are preserved by salting, and are sold for manufacture into an excellent grade of durable leather suitable for making shoes, traveling bags, and numerous other articles. The fat beneath the skin is rendered into oil which is used as elsewhere mentioned. The large canine teeth are shaped, polished, drilled, mounted with gold or silver, and thus converted into cigarette holders which are popular in Uruguay and Argentina. In 1922, the Lobos Islands yielded 3,037 sea-lion skins and other islands 1,252 skins. In the previous year only 683 sea-lions were killed on the Lobos Islands, while in 1919 the figures were 4,401 for the Lobos Islands and 2,652 for other islands.

\section{Nomenclature of the Antarctic Seal}

There are no wolves in the countries of South America on whose coasts fur seals and sea-lions occur. There is no equivalent of the word seal in the Spanish language of those countries. The name lobo (wolf) has in consequence come to be generally applied to seals: in Argentina, Chile, and Uruguay; and a glance at a detailed map of the coast of those countries will disclose various islands and promontories designated by the name of lobo. The term is not a particularly happy one, as, aside from the circumstance that these animals go in herds, there is nothing about them to suggest the predatory wolf. By far the best name for the seals, from the stand- 


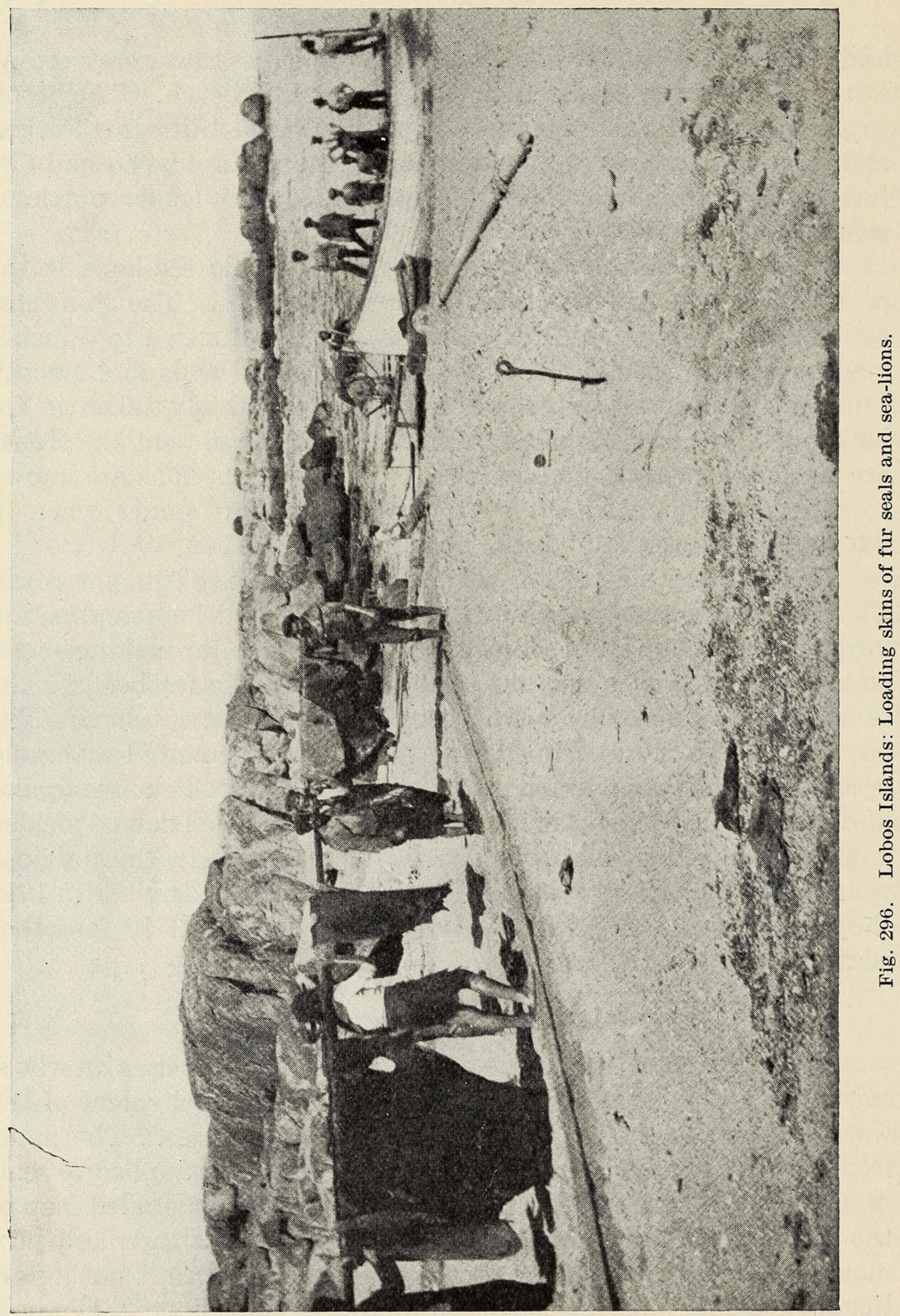


point of anatomy, is sea-bears, which name the antarctic fur seal is entitled to share with its cousins of the North Pacific.

In Uruguayan usage, the fur seal is specifically designated the "lobo fino" and the sea-lion the "lobo ordinario" or "lobo comun." The young are called "chicos," the females "lobas," the males "machos," and the old males or bulls "machos grandes." The trade designation of the skins of the old male seals, whether from Alaska or Uruguay, is wigs.

\section{The LoBos IsLandS}

The Uruguayan seal islands are popularly but erroneously regarded as being synonymous with the Lobos Islands; and in the fur markets of the world all fur-seal skins from Uruguay are designated "lobos" to distinguish them from the pelts from Cape of Good Hope and other southern regions. As a matter of fact, while the Lobos Islands are the largest, best known, and most accessible, there are several other distinct groups of islands to which fur seals resort, and the numbers of seals taken on the minor islands have at times exceeded those killed on the Lobos group.

The Lobos Islands, lying 10 kilometers off Punte del Este, Department of Maldonado, are usually cited in works of reference as located in the mouth of the Rio de la Plata. The trend of the coast from Montevideo to Maldonado is in general a continuation of the left bank of the estuary of the Plata, but it does violence to the physical and biological facts to regard the Lobos Islands, with their typical marine littoral fauna and surrounded by water of high salinity, as being in the mouth of the Plata.

The Lobos group consists of a main island, an outlying low islet, and a number of small detached rock masses over which the surf breaks. Lobos Island proper is about one kilometer long and half a kilometer wide, with a maximum height of 20 meters, and is composed mainly of exceedingly rugged granite ledges, boulders, and cliffs, in places left in fantastic shapes by the volcanic upheaval of which evidences remain in small smooth laval areas and outcropping honeycombed laval rocks in the interior of the island. A shallow soil of sand, shells, and humus supports a sparse stunted vegetation of which conspicuous elements are a harsh brake and a diminutive cactus. Sandy beaches are few in number and of limited extent, the principal beach, at the northwest end, being the only safe boat 
landing and having determined the location of government houses connected with the sealing industry, a lighthouse, and a wireless station. There are no harbors, and landing is at times difficult, if not precarious, owing to the heavy swell and strong currents. The southern part of the island has the most elevated and broken shore, a striking feature being a huge, semi-detached castle-like buttress, with precipitous sides and numerous ledges and crevices to which the seals resort, the base being surf-beaten.

Seals were observed on nearly every rod of the shore, and a few were found well back from the water on the steep slopes of the cliffs or on the topmost boulders. Even at the landing place where men were on the shore and boats were constantly going and coming there were a few seals sleeping or basking on the boulders or sleeping in the surf. At some places where the configuration of the shore appeared attractive or favorable, there were large accumulations of seals, some thousands being in a more or less compact mass.

The most striking feature of the seal life on Great Lobos Island is the heterogeneous mixture of seals of all ages and both sexes. Whereas on the seal islands of Alaska, Kamtchatka, and the Kuriles there is a definite organization of the herd on land, it is difficult on any of the Uruguayan islands to recognize that segregation which the fur seals naturally maintain. The family unit, the harem, in command of a single male always vigilant and ready to give battle to an intruder, was rarely to be seen. The almost invariable condition at all points on the shore was the absence of groups of cows in harem formation. There was a general preponderance of old bulls, constantly engaged in fierce fights. The normal harems that were noted could have been counted on the fingers of one hand. Usually any semblance of a small harem was marred by the presence of pugnacious bulls that sometimes outnumbered the cows. In the incessant fighting, helpless pups were crushed or injured, and in many cases that came under personal observation the young were killed within a few minutes of their birth by being caught beneath the huge bodies of the struggling bulls. The young males and females, which normally haul out by themselves, occupying areas back from the rookeries and never entering the harems, were mingled with the adults throughout the island. The disorganized condition that prevails at the Lobos Islands exists also on the other seal islands and is to be attributed to the reckless sealing methods which have long been followed. 
Old sealers estimated the number of seals at the Lobos Islands in December, 1922, at 20,000, including 5,000 new-born pups. The difficulties in the way of making even an approximately accurate census of the seals under present conditions are formidable, if not insuperable. The opinions of persons who have spent years on the group are entitled to weight, but the writer's feeling is that the above estimate is too large, by possibly 50 per cent.

\section{Other Animals of the Lobos Group}

The larger of the Lobos Group is the only island of sufficient size and remoteness from the mainland to have acquired much individuality in the matter of its fauna.

When I landed there and inquired what animals besides seals and sea-lions one would be likely to find, I was told that among other things there was a "bicho colorado," which being interpreted means simply red beast. Request for more specific information evoked only smiles and the statement that no visitor had ever failed to find it among the ferns. By lunch time a few bichos colorados had been detected and by evening they were greatly in evidence. They proved to be merely chiggoes, with the same insinuating ways that North American chiggoes have.

The most conspicuous land mammal is a rabbit or conylocally known as conejo de la India - said to have been brought here many years ago by sailing ships that touched at Lobos on their way home from the orient. It is nearly as large as a jack rabbit of the western plains of the United States, and occurs in some abundance among the grass and ferns, ambling off leisurely when disturbed.

The most interesting of the land mammals is a tailless rodent about the size of a common gray rat and identified as a native "guinea-pig" (Gaira). It is found all over Uruguay, and bears the Spanish name of quis. It lives in holes in the laval rock and in the densest vegetation, and is a prey of various predatory birds living on the island but its principal enemy is a large owl (buo) that comes from the mainland at night. The quis is now comparatively rare on Great Lobos Island.

\section{The ToRRes IsLANDS}

The northern coast of Uruguay is sadly in need of attention from a modern geographer and surveyor. Many of the geographical names are confused and uncertain, and will remain so until a com- 
plete official survey is made. Consultation of a dozen available Uruguayan maps (some issued by the government, some by private persons) reveals a hopeless lack of uniformity in names. The British Admiralty chart for the Rio de la Plata, many of the data thereon obtained over 60 years ago, is in general use among the local navigators on this coast and affords the best information as to depths, shoals, and general hydrographic features, but it is necessarily obsolete in various respects and many of the names employed are not recognized in modern local usage. The chart, republished in 1869, embodies some detailed surveys made by the French in 1861 . The United States Hydrographic Office chart for the Rio de la Plata and approaches (No. 930, 1886) covers this coast but is on too small a scale to be useful in clarifying the nomenclature of the seal islands.

The first islands north of the Lobos Islands to which fur seals now resort are off Cape Polonia and are designated Torres Islands on American, British, and Uruguayan charts. The separate islands are unnamed on the American chart but on the British chart they are called Encantada, Islote, and "H. W. rock". (the largest). On another edition of the British chart the islands are designated Seca, Encantada, and Islote. The local usage, however, applies the name Raza to the first of these islands and places Seca in another group.

All of these islands are small, rocky, and difficult to reach owing to the prevalence of heavy surf and the absence of beaches. It is only in the calmest weather that sealers are able to land, and it is to this circumstance that the seals obtain almost the only protection they have. The local waters are infested with large sharks which prey on the seals and interfere with the operations of the seal hunters.

Very few seals were found on Raza Island, owing doubtless to its nearness to Cape Polonia and its easy accessibility to sealers. Encantada Island, on the other hand, had its shores well lined with seals, which occupied also parts of the interior and the highest rock masses toward the center. Not less than 500 seals were observed on this island, but this number may have been much less than the actual total, as the extreme ruggedness of the shore precludes the possibility of seeing all the seals. One model harem of 16 cows and one bull was observed, but elsewhere the old males were unduly numerous and several were engaged in fierce combats. One small table rock at the water's edge had as its sole occupants a new-born 


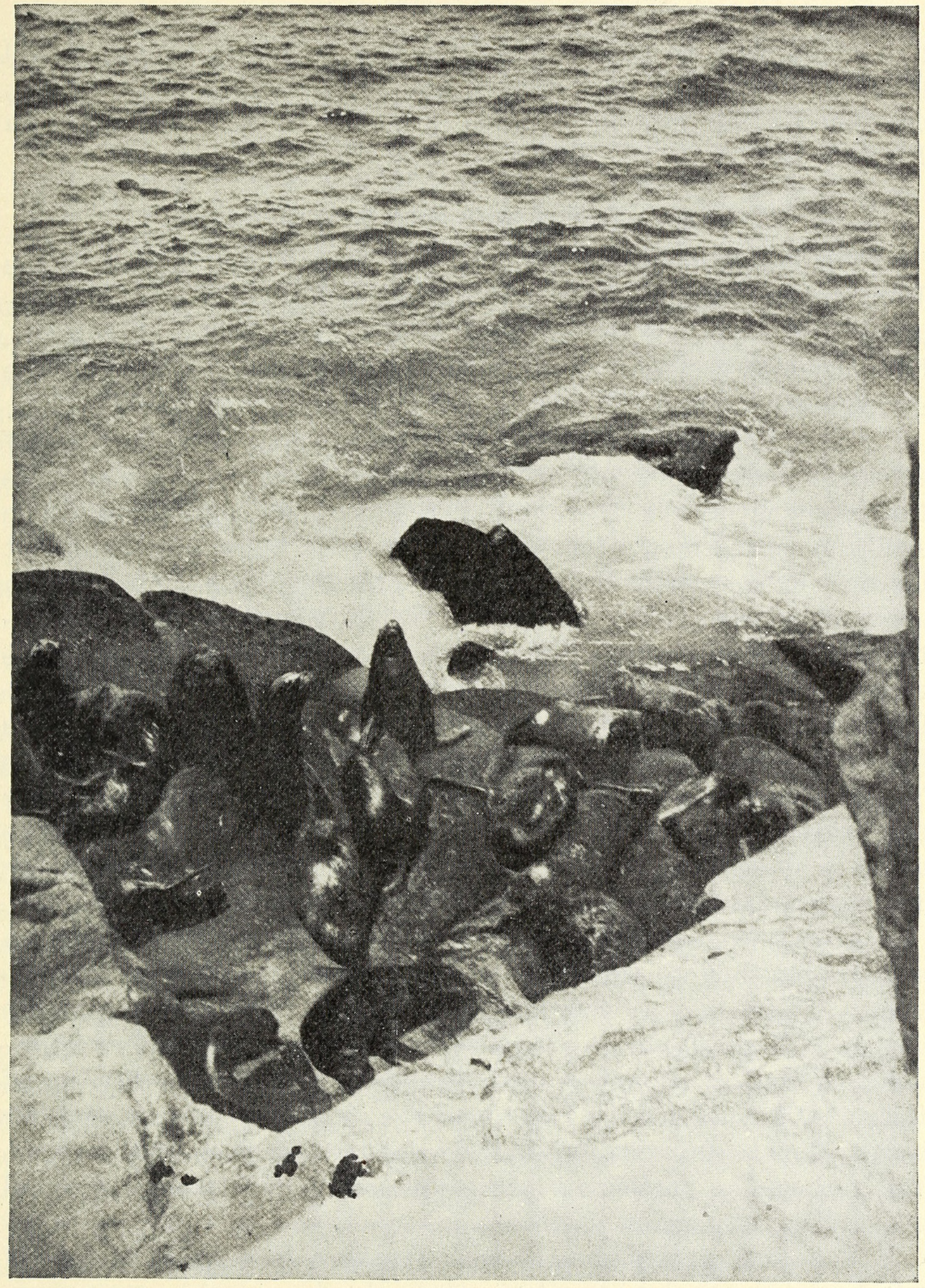

Fig. 297. Lobos Islands: A protected pocket on the surf-washed shore. About twentyfive fur seals, mostly mature females, are crowded in the $\mathrm{V}$-shaped pocket, taking refuge from the surf. 
pup of perhaps 10 pounds weight and a patriarchal male of 750 pounds. Islote, the most remote and most exposed of the group, contained a fair number of seals, probably in excess of those on Encantada.

\section{Cape Polonia and the Sand Dunes}

The northern sealing headquarters are at Cape Polonia, in the Department of Rocha. Clustered near the base of a modern highpower light-house are the residence of the government sealing agent, huts occupied temporarily by the sealing force, houses in which the seal skins are salted and stored, and an oil-reduction plant.

Cape Polonia is a conspicuous rectangular promonotory of colossal granite ledges and boulders, flanked by broad sandy beaches that slope evenly backward and merge into high sand dunes. The sand dunes, reaching a height of 40 meters or more, are the salient feature of the coast of Uruguay, and in the vicinity of Cape Polonia are particularly striking on account of their height and their continuation for mile after mile without interruption. Interest in the sand dunes is increased by the fact that they contain fulguritesfragile tubes of vitrified sand formed by bolts of lightning. These fulgurites came under the observation of Charles Darwin, and in his "Journal of researches into the natural history and geology of the countries visited during the voyage of H. M. S. Beagle round the world," he records on July 26, 1832, that in a sand-hillock near Maldonado he dug out by hand a fulgurite 5 feet 3 inches long.

After our steamer had come to anchor half a mile offshore in a shallow bay behind the cape, it gave several long blasts from its siren. These had no significance to me at the time, but in the course of 15 or 20 minutes their meaning became clear when horsemen, solitary or in small groups, began to appear on the sky line of the dunes headed for the beach and the settlement; and in an hour about 40 men, summoned from their ranches lying behind the dunes, had gathered to participate in the annual loading of seal skins and oil on the government vessel.

The local waters abound with excellent food fishes several of which are identical with, while others closely resemble, species occurring on the east coast of the United States. Schools of sea mullet and menhaden were observed, and on two occasions five-pound bluefish were caught by trolling. In tidepools and potholes among 
the surf-washed granite rocks there were found specimens of a large toad, first met with at Montevideo.

\section{The CASTILlo Islands}

To the north and within sight of Cape Polonia is another cluster of small islands lying off a low, sandy tongue of land designated as Coronilla Point on the British Admiralty charts but called Punte de Castillos Grandes on a chart issued by the Uruguayan director-general of public works in 1893. To complicate the situation, the latter chart gives Islas Castillos Chicos as the name of the group, which contains two main islands. One of these, rather close inshore, called Seca (dry, that is, seal-less) in current Uruguayan usage, is designated Little Castillo Island on the British Admiralty chart. It is a confused mass of granite boulders and ledges reaching a height of 12 meters and appears to be well suited for seals, but in recent times at least has been entirely avoided by these animals.

Lying about 1.5 kilometers due east of Little Castillo or Seca Island is the second member of the Castillo group, an island with several names. The British Admiralty chart designates it Great Castillo and assigns to it a height of 100 feet; the U. S. Hydrographic Office chart calls it Castillo Grande Island and gives it an elevation of 102 feet; but the Uruguayan navigators and local residents know this bit of land as Isla del Marco, following an Atlas Geographico de la Republica Oriental del Uruguay published at Montevideo in 1891. Marco now ranks second in importance among the Uruguayan seal islands, and is the most rugged and least accessible to man of all of them. To the circumstances of its comparative inaccessibility may be attributed the fact that it is now resorted to by more seals than any other island except the larger Lobos. It rises directly from the open sea, without beaches, and is composed entirely of granite boulders, ledges, and massive blocks, those near the water being wave worn, while those further back are as sharply outlined as though fractured and piled up by recent volcanic action. Toward the center of the island, great granite blocks standing on end form an elevated mass that is a conspicuous landmark for sailors. Extending into the island are deep fissures and long, low caverns into which the seals go. There are also huge pot-holes to which the seals resort.

Sealing at Marco Island is attended by thrills and dangers. In following the seals into the caverns, the hunters are in very close 


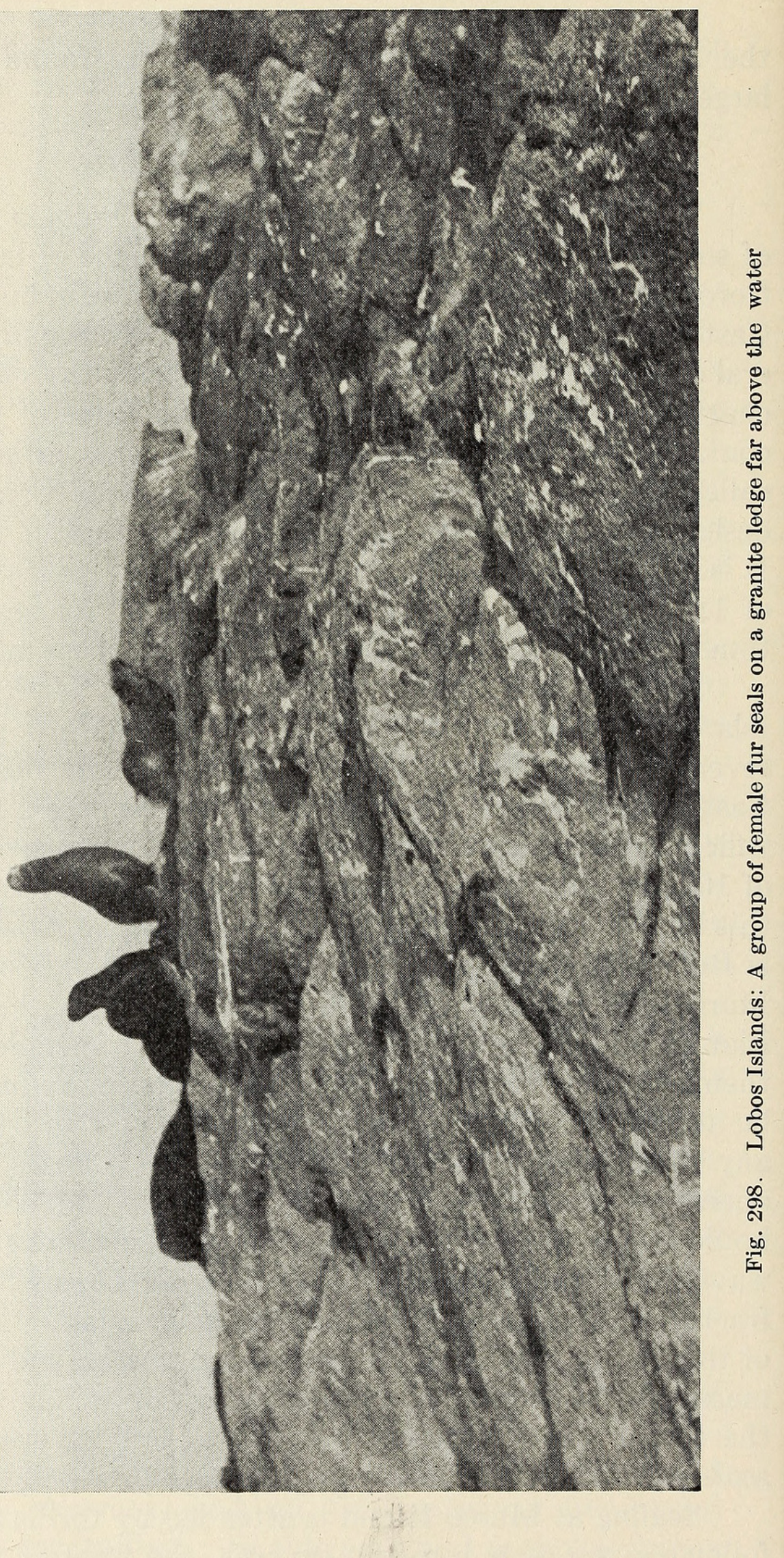


quarters, and a number of them have been bitten by the seals. The principal excitement, however, comes from sharks. These waters abound in large, predatory sharks that are easily able to capture and devour seals at sea and are attracted to the island by the carcasses and blood of the slain seals. There being no landing places, the sealers have to leave their boats and wade ashore. It frequently happens that before the hunters can land and begin operations they have to fight off the sharks. If the hunters can be believed, the sharks will seize the dead seals on the rocks near the water's edge; and it is a fact that freshly-taken skins, while being washed in sea water, have been literally torn from the hands of the sealers by the ravenous sharks.

\section{The CoRonilla Islands}

The most northern islands on the coast of Uruguay are the Coronilla group, lying in latitude $33^{\circ} 56^{\prime}$ S., about 17 kilometers to the southward of the Chuy River which marks the boundary between Uruguay and Brazil. These islands are resorted to by both fur seals and sea-lions, and are the northern limit of the range of these animals on the east coast of South America. The group consists of two main islands and several islets, and lies about $2 \frac{1}{2}$ kilometers offshore, off a promontory sometimes designated as Punte de los Loberos but unnamed on most charts.

The larger island is landward and eight-tenths of a kilometer long. The low northern end is composed of granite ledges and boulders, with a considerable soil-covered area planted with cane and oats about an abandoned sealing plant. The higher southern end is very rugged, with extensive fissured granite ledges and huge boulders. The shore has no landing places but inside the surfwashed boulders there are half a dozen flat sandy or shelly areas. In some places the shells, washed in by the storm waves, are in great variety and of exquisite beauty and are in beds several meters thick. Wherever there is vegetation and in and about the abandoned buildings, there exist untold thousands of large land snails, including two edible species introduced into Uruguay from Europe many years ago and now found all over the country. Conspicuous birds resident on the island were a black-backed gull, abundant and nesting, a few eggs observed, many downy young running about; a small tern, nesting; the teru-tero, or lapwing, a number of old birds 
observed and several young caught by the Uruguayan sailors who stated that the birds are easily tamed and make interesting household pets; the black oyster-catcher, several adults seen and a nearly grown bird and two downy young brought aboard the vessel; a black cormorant, numerous; a red-breasted grebe, a nearly fullgrown young of the year caught in tall grass; and a colony of orioles nesting in the cane-brake.

The other island is exceedingly rugged, and its entire surface is covered with granite boulders and fissured ledges, so that vegetation is sparse. Owing to the absence of landing places and the prevalence of heavy surf and ground swell, the island is difficult to reach.

The Coronilla Islands were once the resort of large numbers of fur seals, and upwards of 2,000 skins have been taken on one island in one season. For several years, however, owing to the scarcity of seals, the government has made no effort to obtain skins, and in 1922 not a single seal was observed on the principal island, although in 1922 and 1923 considerable numbers of seals were noted on the outer, less accessible island. There is little doubt that, in the absence of a government guard, private sealing has occurred and has hastened the decline in this section.

On the main island, seven large sea-lions were the sole occupants of the portion of the shore where the sealers found it possible to land through the surf. As our boat approached, they took to the water and disappeared for a few moments, and then the entire band came to the surface and in a regular line swam fearlessly to within a few rods of the boat, apparently moved by an inordinate curiosity.

The geographical status and the names of the Coronilla Islands are hopelessly confused on Uruguayan charts and maps, no two of which are in agreement. Thus, an Atlas Geographico de la Republica Oriental del Uruguay published at Montevideo in 1891 does not show the group of seal islands but represents in a different position a group of three islands of uniform size designated Coronilla, Castillos Chico, and Santa Tereza; while an Atlas Escolar de la Republica Oriental del Uruguay published at Montevideo about 1910 shows, on the special map for the Department of Rocha, a single island (Coronilla) north of Sealers Point and a single island (Verde) south of that point, no other islands being represented on this part of the coast. 


\section{A Rare Uruguayan Seal}

There occasionally wanders to the Uruguayan coast and is observed on the seal islands a straggling example of the leopard seal, more properly known as Weddell's seal (Leptonychotes weddelli), which is at home among the ice and snow of the far south. Its hair is short, stiff, and of a tawny color, its neck is short, its body is very wide in proportion to its length, and its short flippers are not used as walking limbs as in the fur seals. This species has been made known to American audiences and readers through the lectures, motion pictures, and writings of Shackleton and Scott. In 1921 a few of these antarctic strays appeared at the Lobos Islands. Several of them were of enormous size - as large as the largest sea-lions. The creature is observed at rather long and irregular intervals at the islands off Cape Polonia, and one that was killed at Raza Island in 1921 was of noteworthy bulk; its salted skin was over 3 meters long (without head and posterior flippers) and nearly as wide. Among old sealers of the Uruguayan coast this seal is known as the "morsa." A specimen two meters long from the Lobos Islands was secured by the writer and is now in Washington.

\section{SEAL OIL For Consumptives}

There was a time, not so long ago, when the use of any kind of oil except that from cod livers in the treatment of tuberculosis would have been scouted. The writer's personal investigations in Norway some years ago showed that while cod livers yielded most of the medicinal oil for which Norway was justly famous, the fishermen and manufacturers had no hesitation in mixing with cod livers the livers of other members of the cod family; and further inquiries indicated that some of the cod-liver oil of commerce was mixed with the excellent oil derived from the blubber of the Newfoundland hair seal. From the standpoint of therapeutics, this mixing, that some might call adulteration, was unobjectionable, for the medicinal virtues of the cod, pollock, and seal oils are essentially identical, depending on their iodine content, on their fuel value, and, as we now know, on their vitamines.

It should, therefore, occasion no surprise but rather be taken as evidence of a changed viewpoint and practice that the Uruguayan government should make a high grade of oil from the blubber fat of fur seals and sea-lions and should utilize this oil in the treatment 
of incipient and developed cases of tuberculosis at hospitals all over the country. The refined oil is supplied gratis by the government, and is sent out in glass jars and carboys. The oil is in great demand; the hospitals keep sending back the empty vessels to be refilled; and some remarkable cures of apparently hopeless cases are recorded. No distinction is made and no appreciable difference is known between the oil of fur seals and the oil of sea-lions; the oils are mixed indiscriminately. In 1921 the production was over 28,000 kilograms.

\section{REMAins of THE ABORIgines}

While historical data are deficient, there is ample archeological evidence that the Uruguayan Indians resorted to the seal islands and made use of the seals. Stone spear-heads and arrow-heads have been found in the wave-washed recesses of some of the islands. At what must have been Indian camp or village sites, on the coast east and north of Maldonado, among remains of fires and primitive utensils, there may still be uncovered charred bones and teeth of seals. On the shores of the Lobos Islands, at Cape Polonia, and at the most remote of the islands now resorted to by fur seals, off Sealers Point, there have been found boleadoras - small, rounded, grooved stones of which a set of two or three, tied at the ends of sinews of the rhea or other wild animals and used by hurling at the quarry, constituted a bola, the characteristic and most effective weapon of the Uruguayan aborigines.

The boleadoras have been found at points where, in historical times, practically the only animals of noteworthy size have been seals and sea-lions, but these creatures are not of a form and habit that would readily permit capture by such means. It is possible, however, that the bolas were sometimes thrown to stun or confuse the seals until the Indians could approach near enough to employ their spears or clubs.

The Indians who resorted to this coast and made and used the stone weapons referred to were the warlike Charruas, whose extermination began soon after the arrival of the Spaniards and was relentlessly pushed during three centuries. Drawn into one of the innumerable revolutions with which Uruguay has been afflicted, the pitiable remnant of the once formidable tribe suffered annihilation in 1830. According to local authorities, the boleadoras here collected by the writer were last used probably not later than 1750 . 


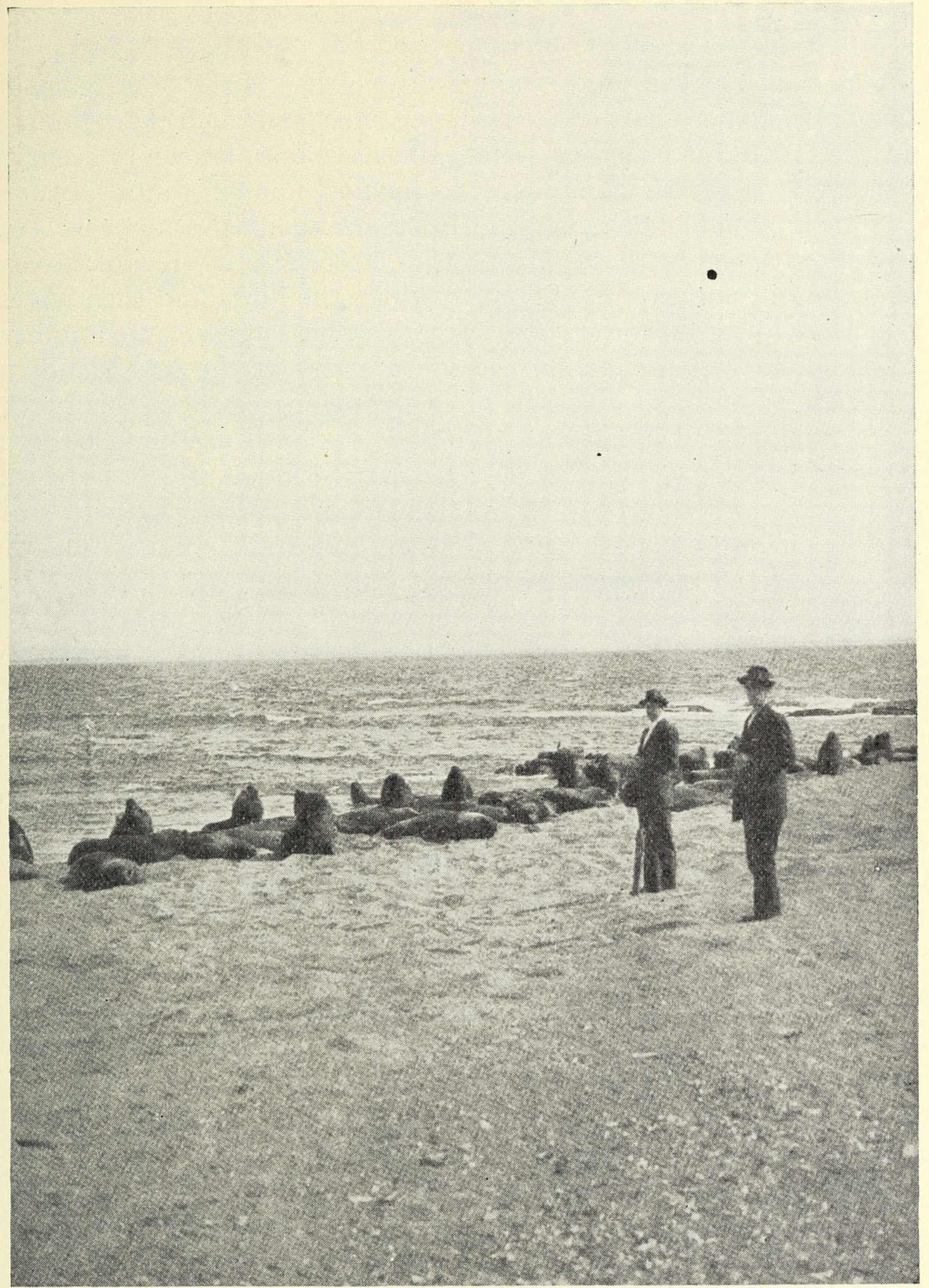

Fig. 299. Lobos Islands: Sea-lions resting on beach of Great Lobos Island. Unless harrassed they are comparatively tame and fearless. 


\section{The Plight of the Penguins}

A curious freak of geographic distribution is the occurrence on the most northern part of the Uruguayan coast of such characteristic antarctic birds as penguins. Penguins have been known to occur as stragglers on the Brazilian coast as far north as $32^{\circ}$ south latitude, but their annual appearance in numbers about the northern seal islands of Uruguay occasions surprise, especially in view of the extraordinarily unfortunate plight in which the birds find themselves.

Every year in winter, that is, in July and August, large numbers of penguins swimming from the south arrive at the seal islands in the vicinity of Cape Polonia. The compelling cause of this northward migration is unknown. Whether the birds are impelled by a perverted instinct, whether they are carried involuntarily by ocean currents, or whether they follow their food supply along with seals and flying birds, is uncertain. The all important point is that the birds resort by thousands to the extensive sandy beaches at Cape Polonia, and that as the season advances and the air and water become warmer they sicken and die. Not one penguin survives until the next fatal migration occurs. Many of the penguins are skinned by the local sealers, who make up the skins into various articles of wearing apparel, but no use is made of most of the carcasses.

Numerous penguin remains were noted by the writer in the shifting beach sand at Cape Polonia in December, and it was learned that as many as 3,000 birds had been known to succumb at that place in a single season. The species was identified as the "johnny" penguin (Pygoscelis papua), which attains the size of a mallard duck, and was entertainingly described and well figured by Dr. Murphy in his most readable article, "South Georgia, an Outpost of the Antarctic" (National Geographic Magazine, April, 1922). The birds nest on South Georgia Island, lying 1,500 miles southeast of Cape Polonia and 1,000 miles east of Cape Horn, and were met with by Murphy "in the wide sea some hundreds of miles north of South Georgia.'

\section{Future of the Uruguayan Seal Herd}

The present Uruguayan seal herd is a mere remnant fast approaching commercial extinction under existing conditions. During the thirteen years ending in 1922 the number of seal skins taken by the government was 19,151 , an average of less than 1,500 yearly, 


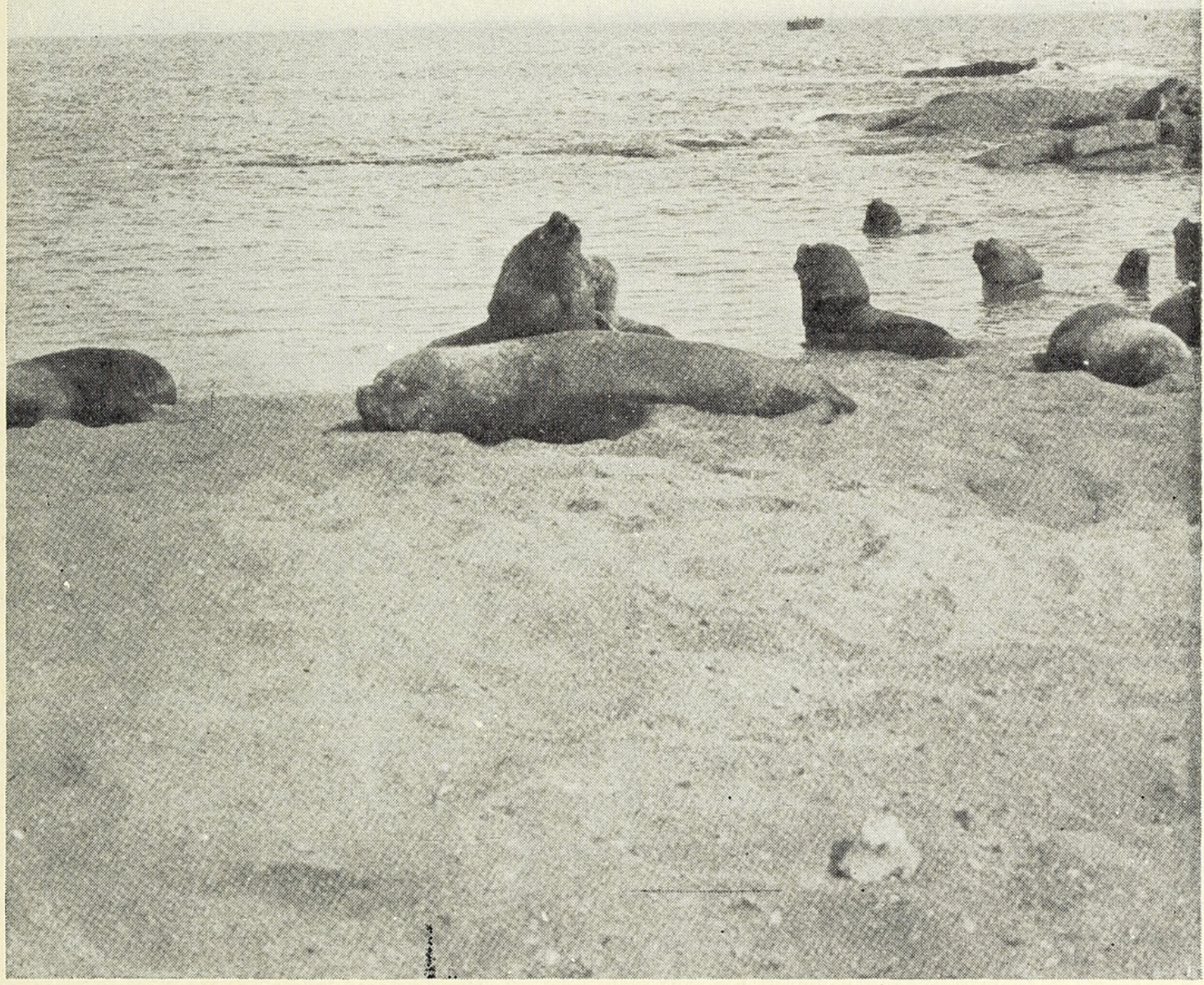

Fig. 300. Lobos Islands: Male sea-lions in a sandy cove. 
against a yearly average of nearly 15,000 in the thirty-five years ending in 1907.

There is little doubt that these seals will quickly respond to an opportunity to reëstablish themselves, and it is confidently expected that so progressive a country as Uruguay will take the steps necessary to restore and maintain this valuable resource.

These seals are not without their international relations, differing in degree but not in kind from those to which the fur seals of the North Pacific Ocean have given rise. An important question may sometime arise between Uruguay and Argentina involving jurisdiction over the seal herd. Inasmuch as the fur seals and sealions migrating to and from their breeding grounds on the Uruguayan coast pass along the coast of Argentina and at times within the territorial jurisdiction of that country, it would be an easy matter for vessels under the Argentine flag to intercept, harass, and kill the seals and thus materially impair the herds to which a sister republic makes claim by virtue of their resorting to her land for breeding purposes. Similarly, it would be easily possible for Uruguayan sealing vessels to operate along the entire coast of Argentina and prey on the seals passing to and from the various islands on that coast.

There would thus be created a situation like that which developed in the North Pacific Ocean and Bering Sea when pelagic hunters, under American, British, and Japanese flags, closely followed the herds of migrating seals and carried on such a ruthlessly destructive industry that the heads resorting to the Alaskan, Kamtchatkan, and Japanese islands were soon sadly depleted, and protracted international controversy ensued before an agreement was finally secured that prevented further decimation and almost certain extinction of the respective herds, and has resulted in a notew ${ }^{\prime}{ }^{\prime} ?$ recuperation.

Uruguay has as yet not entered into any coöperative arrangement with Argentina for the protection of fur seals and sea-lions, but the time is ripe for international action to supplement national regulation that will save the shattered seal herds from total extermination. 


\section{$2 \mathrm{BHL}$ Biodiversity Heritage Library}

Smith, Hugh M. 1927. "The Uruguayan Fur-Seal Islands." Zoologica : scientific contributions of the New York Zoological Society 9(6), 271-294.

https://doi.org/10.5962/p.203746.

View This Item Online: https://www.biodiversitylibrary.org/item/208079

DOI: https://doi.org/10.5962/p.203746

Permalink: https://www.biodiversitylibrary.org/partpdf/203746

\section{Holding Institution}

Smithsonian Libraries

\section{Sponsored by}

Biodiversity Heritage Library

\section{Copyright \& Reuse}

Copyright Status: In Copyright. Digitized with the permission of the rights holder

Rights Holder: Wildlife Conservation Society

License: http://creativecommons.org/licenses/by-nc/3.0/

Rights: https://www.biodiversitylibrary.org/permissions/

This document was created from content at the Biodiversity Heritage Library, the world's largest open access digital library for biodiversity literature and archives. Visit BHL at https://www.biodiversitylibrary.org. 